\title{
A Morphological and Stereological Study on Cervical Spinal Cord of One and Five Months Age Male Rat
}

\author{
Mesude CANDAN ${ }^{1}$, Gamze ÇAKMAK ${ }^{2 *}$ \\ ${ }^{1}$ District Education and Research Hospital, Van, Turkey \\ ${ }^{2}$ Department of Anatomy, Faculty Veterinary Medicine, University of Van Yuzuncu Yil, Van, Turkey \\ (ORCID: 0000-0002-1250-2150) (ORCID: 0000-0002-3970-3040)
}

\begin{abstract}
In this study volume density of gray and white matter of cervical segments of spinal cords of rats were investigated using stereological method. Twelve male Wistar albino rats were used in the study as two different age groups 1 month and 5 months. All animals were fixed by perfusing $10 \%$ buffered formalin. Rats were dissected and spinal cords of rats were removed. In the study cervical segments of 1 and 5 months age rats were obtained. One of the first 15 section were selected randomly when the sections were taken. And following every 50th section was determined by systematic random sampling. Thus, 8-10 sections of $5 \mu \mathrm{m}$ thickness were obtained from cervical segments of each animal's medulla spinalis. These sections were stained by hemotoxylin eosin and they were photographed at microscope. Densities of volumes of all tissue of cervical segments of whole spinal cord and white and gray matters were calculated using dotted area ruler by Cavalieri Principle. SHTEREOM 1.5 package programme was used for counting dotted area. In addition, the volume vales of total cervical segment, volume values of the white matter and the gray matter and the ratios of these volume values to each other were evaluated in the study.
\end{abstract}

Keywords: Volume, spinal cord, rat, cervical segment, stereology.

\section{Bir Aylık ve Beş Aylık Erkek Ratlarda Medulla Spinalis'in Servikal Segmenti Üzerine Yapılan Morfolojik ve Stereolojik Bir Çalışma}

\begin{abstract}
Öz
Bu çalışmada ratlarda medulla spinalis'in servikal bölümünün ak ve gri madde ve tüm dokunun hacim yoğunlukları stereolojik yöntem kullanılarak araştırıldı. Materyal olarak 1 aylık ve 5 aylık olmak üzere iki farklı yaş grubundan altışar adet erkek Wistar Albino urkı ratlar kullanıldı. Materyaller \% 10'luk tamponlu formaldehitle perfüze edilerek tespit edildi. Daha sonra ratlar diseke edildi ve medulla spinalis'leri açığa çıkarıldı. Çalışmada 1 aylık ve 5 aylık ratların medulla spinalis'lerinin cervical bölümlerinden segmentler elde edildi. Kesitler alınırken ilk 15 kesit arasından rasgele bir tanesi seçildi. Onu takip eden her 50.kesit sistematik rasgele örnekleme yöntemiyle belirlendi. Böylelikle bir hayvanın medulla spinalis'inin cervical segment'inden $5 \mu \mathrm{m}$ kalınlığında 8-10 kesit alındı. Bu kesitler hematoksilen eosin boyama tekniği ile boyanarak mikroskop altında fotoğraflandi. Cavalieri Prensibi kullanılarak noktalı alan cetveli sayesinde medulla spinalis'in cervical bölümünün her bir segmentinde tüm dokunun, ak madde ve gri madde kısımlarının hacim yoğunlukları hesaplandı. Noktalı alan sayımı için SHTEREOM 1.5 paket programı kullanıldı. Ayrıca araştırmada cervical segmentin tüm hacminin, ak madde ve gri madde hacim değerleri ve bu hacim değerlerinin birbirlerine oranları hesaplanarak değerlendirildi.
\end{abstract}

Anahtar Kelimeler: Hacim, medulla spinalis, rat, servikal segment, stereoloji.

*Corresponding author: vetgamze@ hotmail.com

Received: 10.12.2019, Accepted: 27.12.2019 


\section{Introduction}

\subsection{Rat}

Rats, generally being active at nights, are the mostly preferred animal group in biomedical studies because they easily adapt to laboratory setting where they live in, are easy to raise, can be reproduced into a large number in a short time, and have small physical structures $[1,2]$.

\subsection{Spine}

Spine is a multifunctional organ that has support and motional function, also undertakes the duty to protect spinal cord found in it and spinal roots separating from spinal cord $[3,4]$. The spine starts with atlas, which is the first cervical vertebrae, and continues until the last sacral vertebrae. It is studied under five different parts. These parts are cervical, thoracic, lumbar, sacral, and caudal parts [5-7].

\subsection{Spinal cord (SC)}

The part of central nervous system in vertebral canal is spinal cord [8]. The spinal cord originates from spinal cord bulb at the level of foramen magnum without showing a macroscopic borderline and terminates with conus medullaris [6]. Even though spinal cord is cylindrical, this cylindrical structure can not maintain this shape throughout its all length. It has two distinct extensions in two separate regions including lumbar and cervical parts [3,7]. Cervical enlargement is an extention in cervical region, lumbal enlargement is an extention region in lumbal part [7]. Cervical enlargement forms by involvement of C6-7-8 and T1-2 segments in all domestic mammals (except for pig), C5-6-7-8 and T1 in human and pork [6]. The spinal cord is divided into five parts including cervical, thoracic, lumbar, sacral, and caudal parts [3].

\subsection{White and Grey Matters}

Two areas, grey and white matter, are distinguished from cross section surfaces of spinal cord. While grey matter (GM) is the central part of spinal cord and is the butterfly or H-like here, white matter (WM) is located outside grey matter and surrounds it and appears in lighter color [3,9]. The grey matter is centrally located in spinal cord. Its all sides is surrounded by white matter central canal is located in the middle of grey matter. This canal proceeding along the length of spinal cord terminates by opening to back to end of fourth ventricle [10]. The white matter generates outer part of spinal cord. It appears white due to excessive myelinated fibers. It is composed of a great number of glial cells [3, 10].

\subsection{Stereology}

Stereology is a discipline which is open to interpretation about concrete three dimensional characteristics of three dimensional objects thanks to data obtained from their two dimensional cross section images or projections (volume, length, area, particle number, etc.) as well as including a chain of objective methods $[11,12]$. One of essential conditions required to increase reliability of data in biological studies conducted is to correctly carry out the sampling stage. Sequential random sampling method is implemented separately in every stage of stereological study including sampling of the tissue which is planned to studied (tissue sampling), histological cross sectioning (section sampling), and examination of these cross sections under microscope (area sampling) [13-17]. Owing to stereological studies, quality and accuracy of numerical measurements can be observed by calculating coefficient of error (CE) [18]. Gundersen et al. [19] reported that a CE value around 5\% and lower is sufficient for reliable results of a stereological study.

\subsection{Cavalieri's Principle}

Significant numeric values which are used frequently consist of volume of an organ, volumes of different components belonging to an organ, and also volume ratios of these components to one another or the 
whole structure $[15,20]$. For calculating total volume of objects the Cavalieri principle is usually used in stereology $[14,15,21]$. Mathematical equation used in the calculation is stated as follows $[15,21$, 22].

Vref : Total or reference volume of the structure studied

$\sum_{\mathrm{t}}$ ai :Total surface area of projection or total projections of the cross section number

$\overline{\mathrm{t}} \quad$ : Mean thickness of cross section or slice

Total volume can be achieved by the equation Vref $=\sum$ aix $\bar{t}$. In the study applying these procedures, total volume of the studied structure is found to be effective and objective [13, 20, 23].

\section{Materials and Methods}

\subsection{Animals}

By Van Yuzuncu Yil University Animal Researches Local Ethic Committee the final report of the research project detailed above was approved in the session held on 12/26/2017 (decision number 2016/09). Healty young male Wistar Albino rats that had a weight of 50-60 gr and were 1 month old and healty adult male Wistar Albino rats that had a weight of 150-200 gr and were 5 month old were used in the study. $50 \mathrm{mg} / \mathrm{kg}$ ketalar was administered i.p to ensure deep anesthesia in animals [24]. 0.5 cc heparin was injected to ventriculus sinister while hearts of rats were beating under anesthesia. The right ventricle of heart was also cut to let the blood stream out. $0.9 \%$ physiological saline solution was administered as intracardiac through a cannula simultaneously until the blood running out from right ventricle became clear (for 5 minutes). Animals were ensured to be fixed by administering formalin with $10 \%$ buffer for 10 minutes using the same method. Rats were dissected after perfusion and fixation processes.

\subsection{Dissection and removal of spinal cord}

Soft tissues around spine of rats were removed by using clamp, scalpel, surgical scissors, and microscissors. Separate tissues were obtained from each spinal cord's cervical segment of all animals (Figure 1, Figure 2). Tissue processing procedure was then applied to these tissues [25].

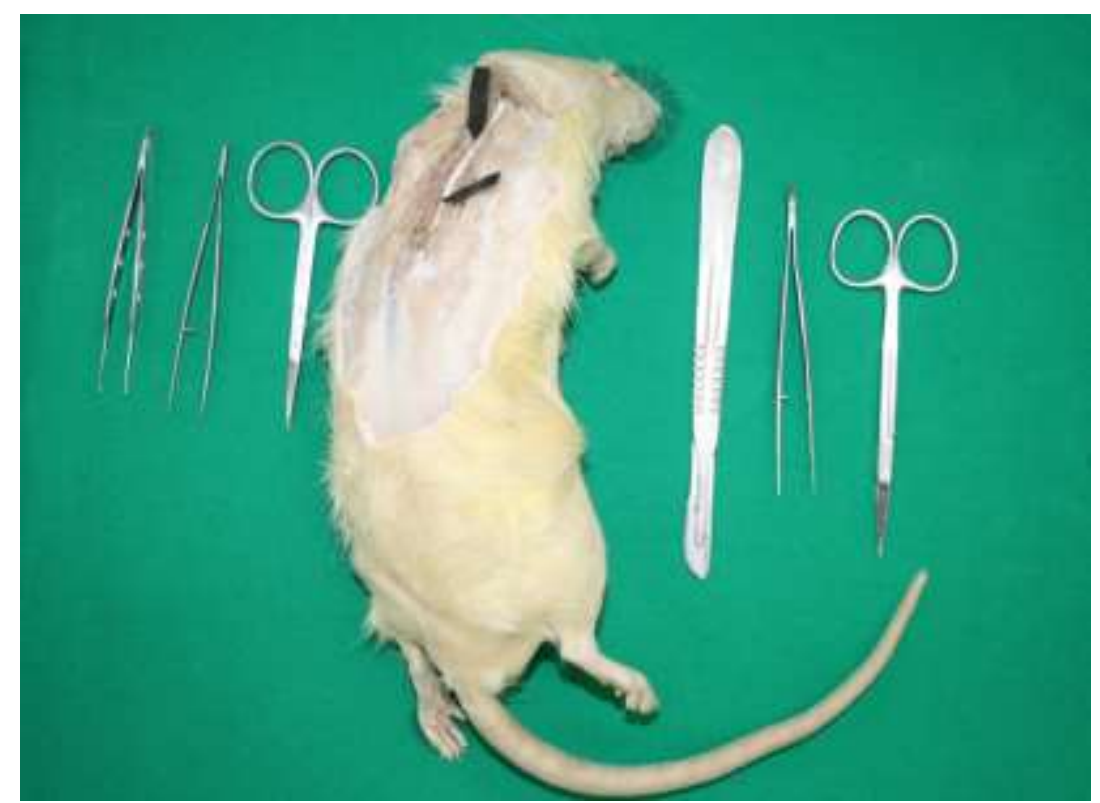

Figure 1. Dissection of cervical segment of rat (5-month-old) 


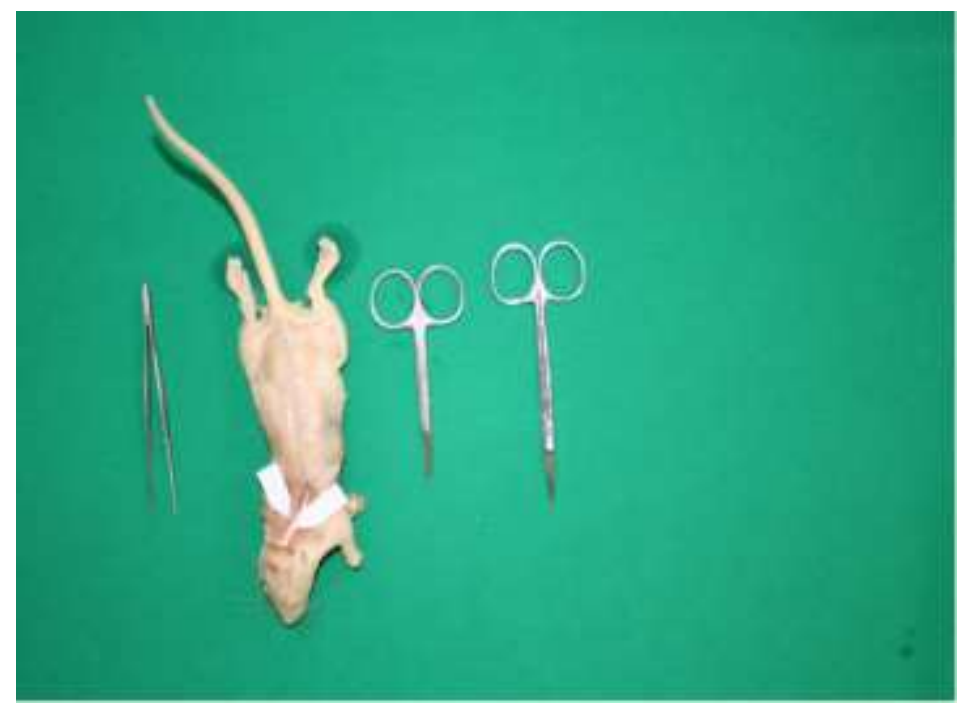

Figure 2. Dissection of cervical segment of rat (1-month-old)

\subsection{Method of Sampling}

A preliminary study was carried out to determine the number of animals and cross sections, and sampling before starting the study. It is reported in existing studies that each group needs to consist of minimum 5 animals to obtain coefficient of error which is approximately 0.05 in stereological studies to be conducted [11]. Pilot study revealed that the number of animals and cross sections numbers, and sampling method were convenient. Segments were removed from spinal cord's cervical parts of 5-month old and 1-month-old rats for the preliminary study. Tissue samples were taken from these segments. Cross sections having a thickness of $5 \mu \mathrm{m}$ were obtained from the cervical segment tissue samples. Averagely 8-10 cross sections were taken from spinal cord's cervical segment of every animal. Section sampling was organized to perform randomly and systematically at the ratio of $1 / 50$ by starting from a random one among the first 15 cross tissue sections. Every $50^{\text {th }}$ cross section were taken following. Sampled cross sections were then included in the study. Cross section processes by microtome were continued based on sampling rates and method in the pilot study after histological processing for spinal cord of rats. To obtain cross sections in the number determined in the preliminary study, cross sections were taken separately from each of cervical spinal segments blocked by being embedded into paraffin. Hematoxylin-eosin staining method were used to stain the cross sections obtained from tissues [25] (Figure 4, Figure 5). Since the spinal cord is a considerably little structure, there was no need for stereological stepping. Pointed area and after that area volume were calculated by numeric aperture $(\mathrm{NA})=0.25$, objective $\mathrm{x} 4$ magnification. For this calculation Shtereom 1.5 software was used (Figure $3)$. The Cavalieri's principle was utilized for the calculation in the program $[14,26]$. Total spinal cord volume, the total volume of grey matter, and volume of the white matter of the 8 segments generating the cervical part of spinal cord were calculated in the present study.

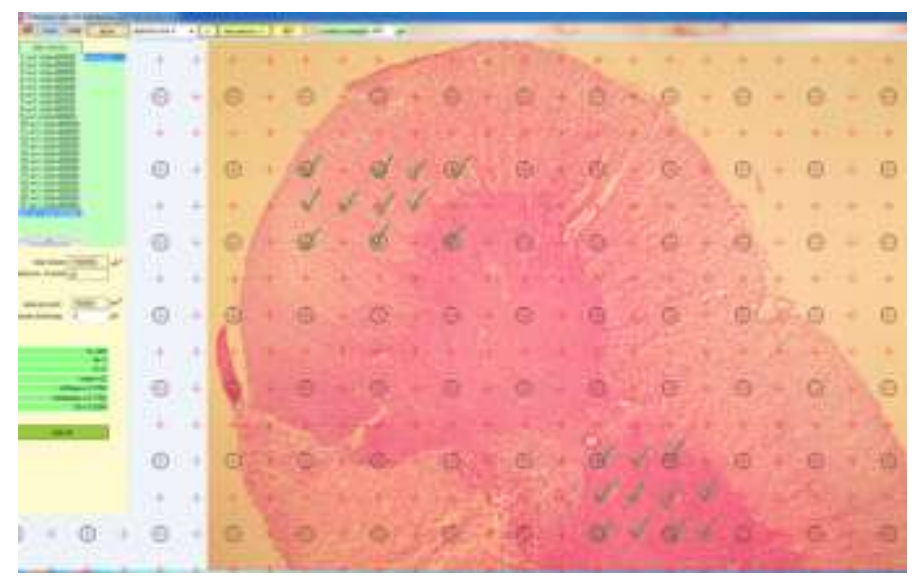

Figure 3. Shtereom 1.5 packaged software 


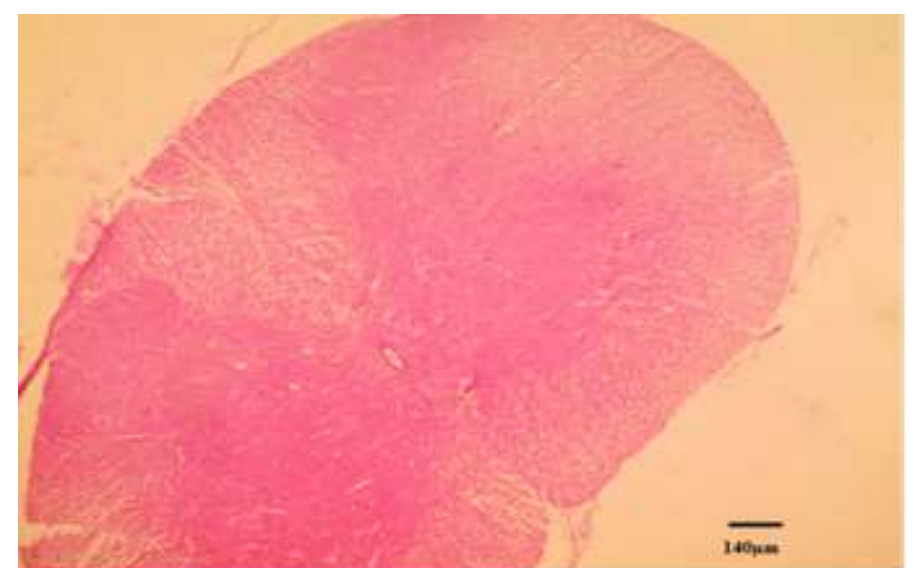

Figure 4. Tissue specimen of cervical segment of 1-month old rat $\mathrm{X} 4$ objective magnification (Hematoxylin eosine)

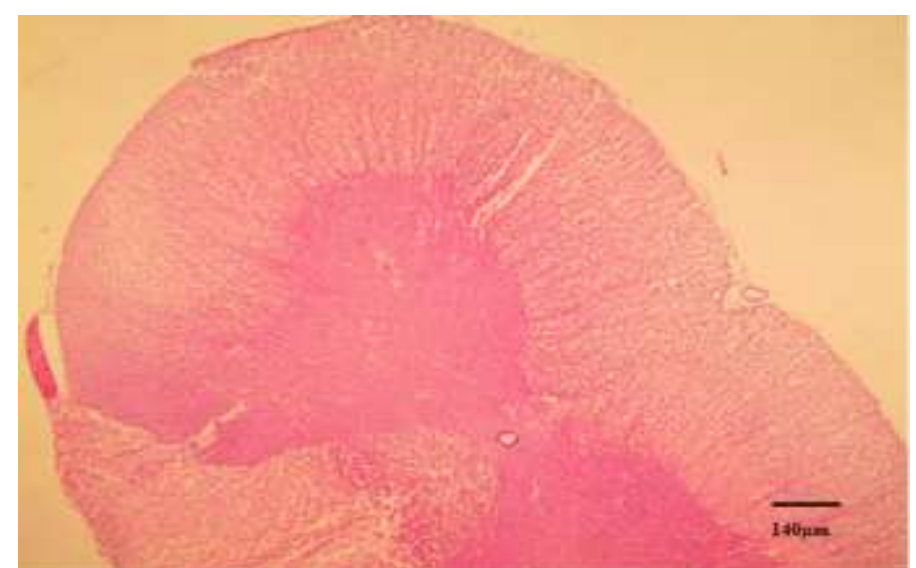

Figure 5. Tissue specimen of cervical segment of 5-month-old rat $\mathrm{X} 4$ objective magnification (Hematoxylin eosine)

\subsection{Equation of volume density}

Volume ratio of white matter in every segment: The number of points corresponding to white matter/the number of points corresponding to the whole cervical segment

Equation of total volume: Volume data of 8 segments were added together for total volume of segments. Equation for volume of cervical segment: Volume ratio $\mathrm{X}$ reference volume of cervical segment Equation for reference volume of cervical segment: Inter-section distance $\mathrm{X}$ actual area of the point $\mathrm{X}$ the number of points

The equation below was used for calculating volume of relevant structures in the study.

Volume $(\mathrm{V})=\sum P i . \mathrm{a} / \mathrm{p}$. (KÖO). (AÖO). $\overline{\mathrm{t}}$

$\sum P i \quad$ : Total number of points

$\mathrm{a} / \mathrm{p} \quad:$ : Area represented by single point

KÖO : Cross section sampling ratio

AÖO : Step sampling ratio

$\overline{\mathrm{t}} \quad$ : Mean thickness of cross section

\section{Results}

All volume, volume values of the grey and white matter of spinal cord's cervical segments of six 1month-old male rats and six 5-month-old male rats, as well as ratios of GM volume to WM volume, ratios of WM volume to all volume measurements of cervical segment, and ratios of GM volume to all volume measurements of cervical segment were separately in this study. As 1-month old male rats were evaluated in terms of the overall volume as a result of the calculations, all volume values of cervical 
segment of $\mathrm{C} 1$ were observed to be higher than all other segments. $\mathrm{C} 4$ value was determined to be 2.102 $\mathrm{mm}^{3}$. The lowest cervical segment volume value belonged to $\mathrm{C} 8$ which was found to be $1.067 \mathrm{~mm}^{3}$ (Table 1). The highest mean volume from white matter measurements of cervical segment of 1-month male rats shown in Table 2 was $1.018 \mathrm{~mm}^{3}$ which belonged to the segment $\mathrm{C} 1$. The highest volume of white matter was $1,009 \mathrm{~mm}^{3}$, which belonged to segment $\mathrm{C} 4$, as well. As grey matter values of one month-old male rats were examined, it was remarkable that volume measurements of segments $\mathrm{C} 1$ and $\mathrm{C} 4$ were higher than volume results of other segments. This value was calculated to be $0.851 \mathrm{~mm}^{3}$ for segment C1. C8 was the segment with the lowest volume in grey matter, which was found to be 0.393 $\mathrm{mm}^{3}$ (Table 2). When ratios of grey matter volume measurements of cervical segment to volume values of white matter for one-month old male rats were examined in Table 2, the highest mean ratio was determined in segment $\mathrm{C} 4$ as 0.85 . The lowest grey matter/white matter ratio was established in segment C8 with 0.64 . When examining ratio of white matter volume values to volume results of whole spine in cervical segment in one-month old male rats, it was revealed that the highest ratio was 0.60 and determined in segment $\mathrm{C} 8$. The lowest ratio of volume was identified in segment $\mathrm{C} 1$ with 0.42 (Table 1). When examining the ratio of volume value of grey matter to spinal cord volume value in Table 1, it was seen that the highest value was 0.43 and belonged to segment C7. The lowest GM /WM ratio was 0.33 and regarded to segment $\mathrm{C} 2$.

Table 1. Volume values of the cervical (C) spinal cord of 1-month-old male rats (Q) (VVSC) (mm³), Volume ratios of the white matter/the spinal cord in the cervical spinal segments of 1 -month-old male rats (WM/SC) (\%),

Volume ratios of the gray matter/the spinal cord in the cervical spinal segments of 1-month-old male rats

$(\mathrm{GM} / \mathrm{SC})(\%)$

\begin{tabular}{|c|c|c|c|c|c|c|c|c|c|}
\hline & & & \multicolumn{6}{|c|}{ Number of Animal } & \multirow{2}{*}{ MEANS } \\
\hline & & & R1 & $\mathrm{R} 2$ & R3 & R4 & R5 & R6 & \\
\hline \multirow{24}{*}{ 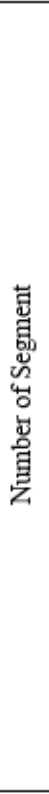 } & \multirow{3}{*}{$\mathrm{C} 1$} & VVSC & 2.138 & 2.238 & 3.646 & 2.378 & 3.204 & 1.388 & 2.498 \\
\hline & & WM/SC & 0.390 & 0.370 & 0.350 & 0.350 & 0.610 & 0.480 & 0.420 \\
\hline & & $\mathrm{GM} / \mathrm{SC}$ & 0.330 & 0.330 & 0.330 & 0.390 & 0.250 & 0.480 & 0.350 \\
\hline & \multirow{3}{*}{$\mathrm{C} 2$} & VVSC & 2.192 & 1.785 & 2.017 & 2.240 & 1.732 & 2.840 & 2.134 \\
\hline & & WM/SC & 0.470 & 0.480 & 0.350 & 0.570 & 0.430 & 0.330 & 0.430 \\
\hline & & $\mathrm{GM} / \mathrm{SC}$ & 0.290 & 0.340 & 0.330 & 0.260 & 0.440 & 0.350 & 0.330 \\
\hline & \multirow{3}{*}{$\mathrm{C} 3$} & VVSC & 2.006 & 1.861 & 2.426 & 2.783 & 1.529 & 1.608 & 2.035 \\
\hline & & WM/SC & 0.450 & 0.460 & 0.340 & 0.630 & 0.600 & 0.310 & 0.460 \\
\hline & & $\mathrm{GM} / \mathrm{SC}$ & 0.340 & 0.360 & 0.250 & 0.290 & 0.470 & 0.480 & 0.360 \\
\hline & \multirow{3}{*}{$\mathrm{C} 4$} & VVSC & 2.247 & 1.755 & 2.713 & 2.595 & 1.647 & 1.660 & 2.102 \\
\hline & & $\mathrm{WM} / \mathrm{SC}$ & 0.380 & 0.300 & 0.310 & 0.650 & 0.740 & 0.570 & 0.490 \\
\hline & & $\mathrm{GM} / \mathrm{SC}$ & 0.320 & 0.410 & 0.300 & 0.280 & 0.500 & 0.490 & 0.380 \\
\hline & \multirow{3}{*}{ C5 } & VVSC & 2.080 & 2.100 & 3.079 & 2.697 & 1.192 & 1.205 & 2.058 \\
\hline & & $\mathrm{WM} / \mathrm{SC}$ & 0.310 & 0.400 & 0.300 & 0.750 & 0.640 & 0.510 & 0.480 \\
\hline & & $\mathrm{GM} / \mathrm{SC}$ & 0.270 & 0.390 & 0.260 & 0.250 & 0.450 & 0.470 & 0.340 \\
\hline & \multirow{3}{*}{ C6 } & VVSC & 1.800 & 1.676 & 2.317 & 2.026 & 1.700 & 0.974 & 1.748 \\
\hline & & WM/SC & 0.450 & 0.380 & 0.310 & 0.690 & 0.690 & 0.410 & 0.480 \\
\hline & & $\mathrm{GM} / \mathrm{SC}$ & 0.360 & 0.330 & 0.330 & 0.380 & 0.340 & 0.480 & 0.370 \\
\hline & \multirow{3}{*}{ C7 } & VVSC & 0.700 & 1.156 & 1.618 & 1.313 & 2.128 & 0.971 & 1.314 \\
\hline & & WM/SC & 0.690 & 0.440 & 0.340 & 0.520 & 0.730 & 0.510 & 0.530 \\
\hline & & $\mathrm{GM} / \mathrm{SC}$ & 0.780 & 0.360 & 0.270 & 0.330 & 0.370 & 0.490 & 0.430 \\
\hline & \multirow{3}{*}{$\mathrm{C} 8$} & VVSC & 1.163 & 0.917 & 1.421 & 1.236 & 0.863 & 0.803 & 1.067 \\
\hline & & WM/SC & 0.550 & 0.450 & 0.400 & 0.770 & 0.860 & 0.570 & 0.600 \\
\hline & & $\mathrm{GM} / \mathrm{SC}$ & 0.360 & 0.390 & 0.290 & 0.280 & 0.460 & 0.500 & 0.380 \\
\hline
\end{tabular}

When whole spinal cord's mean volume values in cervical segments of 5-month old male rats were viewed, it was seen that the highest volume was $2.565 \mathrm{~mm}^{3}$ and regarded to segment $\mathrm{C} 1$. The lowest value belonged to segment C8 and was 1.566. (Table 3). In Table 4, examination of white matter values of 5-month-old male rats revealed that the highest mean volume value was $1.248 \mathrm{~mm}^{3}$ and belonged to segment $\mathrm{C} 2$. The lowest volume value was calculated as $0.866 \mathrm{~mm}^{3}$ and belonged to segment C8. When examining the volume values of the grey matter determined in cervical segment of 5 -month old male rats (Table 4), it was observed that volume value of segment $\mathrm{C} 1$ was $0.714 \mathrm{~mm}^{3}$. The lowest value of the volume was $0.349 \mathrm{~mm}^{3}$ and belonged to segment C8. While the highest GM /WM volume ratio in 5-month old male rats was 0.62 for segment $\mathrm{C} 3$, the lowest mean GM /WM volume ratio was 0.33 for segment $\mathrm{C} 8$ (Table 4). When WM/SC volume ratios were examined in Table 3, it was revealed that the highest mean $\mathrm{WM} / \mathrm{SC}$ value was 0.55 and this value was determined in both segment 
$\mathrm{C} 6$ and segment $\mathrm{C} 8$. The lowest mean WM/SC value belonged to $\mathrm{C} 5$ segment and determined to be 0.45 . When the ratio of volume of the grey matter to volume of whole spinal cord in 5 month-old male rats was evaluated, the highest volume ratio belonged to segment $\mathrm{C} 3$ and this value was determined to be 0,30 . The lowest volume ratio was determined in segment $\mathrm{C} 8$ with 0.21 (Table 3 ).

Table 2. Volume values of the white matter of the cervical (C) spinal cord of 1-month-old male rats (Q) (VVWM) $\left(\mathrm{mm}^{3}\right)$, Volume values of the gray matter of the cervical spinal segments of 1-month-old male rats $(\mathrm{VVGM})\left(\mathrm{mm}^{3}\right)$, Volume ratios of the gray matter/the white matter in the cervical spinal segments of 1-monthold male rats (GM/WM) $(\%)$

\begin{tabular}{|c|c|c|c|c|c|c|c|c|c|}
\hline & & & \multicolumn{6}{|c|}{ Number of Animal } & \multirow{2}{*}{ MEANS } \\
\hline & & & R1 & $\mathrm{R} 2$ & $\mathrm{R} 3$ & R4 & R5 & R6 & \\
\hline \multirow{24}{*}{ 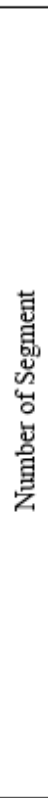 } & \multirow{3}{*}{$\mathrm{C} 1$} & VVWM & 0.848 & 0.832 & 1.296 & 1.145 & 1.133 & 0.858 & 1.018 \\
\hline & & VVGM & 0.720 & 0.741 & 1.213 & 0.940 & 0.823 & 0.669 & 0.851 \\
\hline & & GM/WM & 0.840 & 0.890 & 0.930 & 0.820 & 0.720 & 0.770 & 0.820 \\
\hline & \multirow{3}{*}{$\mathrm{C} 2$} & VVWM & 1.050 & 0.859 & 0.709 & 0.743 & 1.004 & 1.232 & 0.932 \\
\hline & & VVGM & 0.653 & 0619 & 0.676 & 0.600 & 0.766 & 1.015 & 0.721 \\
\hline & & GM/WM & 0.620 & 0.720 & 0.950 & 0.800 & 0.760 & 0.820 & 0.770 \\
\hline & \multirow{3}{*}{$\mathrm{C} 3$} & VVWM & 0.914 & 0.864 & 0.840 & 0.865 & 0.976 & 0.972 & 0.905 \\
\hline & & VVGM & 0.697 & 0.672 & 0.622 & 0.816 & 0.728 & 0.775 & 0.718 \\
\hline & & GM/WM & 0.760 & 0.770 & 0.740 & 0.940 & 0.740 & 0.790 & 0.790 \\
\hline & \multirow{3}{*}{$\mathrm{C} 4$} & VVWM & 0.856 & 0.537 & 0.856 & 1.501 & 1.076 & 1.232 & 1.009 \\
\hline & & VVGM & 0.735 & 0.737 & 0.836 & 0.738 & 0.835 & 0.828 & 0.784 \\
\hline & & GM/WM & 0.850 & 1.370 & 0.970 & 0.490 & 0.770 & 0.670 & 0.850 \\
\hline & \multirow{3}{*}{ C5 } & VVWM & 0.654 & 0.846 & 0.943 & 1.389 & 0.900 & 0.782 & 0.919 \\
\hline & & VVGM & 0.568 & 0.837 & 0.829 & 0.695 & 0.545 & 0.572 & 0.674 \\
\hline & & GM/WM & 0.860 & 0.980 & 0.870 & 0.500 & 0.600 & 0.730 & 0.750 \\
\hline & \multirow{3}{*}{$\mathrm{C} 6$} & VVWM & 0.813 & 0.646 & 0.738 & 0.835 & 1.180 & 0.683 & 0.815 \\
\hline & & VVGM & 0.654 & 0.568 & 0.765 & 0.776 & 0.580 & 0.476 & 0.636 \\
\hline & & GM/WM & 0.800 & 0.870 & 1.030 & 0.930 & 0.490 & 0.690 & 0.800 \\
\hline & \multirow{3}{*}{$\mathrm{C} 7$} & VVWM & 0.488 & 0.511 & 0.560 & 0.674 & 1.118 & 0.716 & 0.677 \\
\hline & & VVGM & 0.548 & 0.421 & 0.445 & 0.434 & 0.802 & 0.481 & 0.521 \\
\hline & & GM/WM & 1.120 & 0.820 & 0.790 & 0.640 & 0.710 & 0.670 & 0.690 \\
\hline & \multirow{3}{*}{$\mathrm{C} 8$} & VWWM & 0.644 & 0.414 & 0.580 & 0.712 & 0.668 & 0.694 & 0.618 \\
\hline & & VVGM & 0.428 & 0.362 & 0.415 & 0.347 & 0.400 & 0.409 & 0.393 \\
\hline & & GM/WM & 0.660 & 0.870 & 0.710 & 0.480 & 0.590 & 0.580 & 0.640 \\
\hline
\end{tabular}

Table 3. Volume values of the cervical (C) spinal cord of 5-month-old rats (Q) (VVSC) ( $\left.\mathrm{mm}^{3}\right)$, Volume ratios of the white matter/the spinal cord in the cervical spinal segments of 5-month-old rats (WM/SC) (\%), Volume ratios of the gray matter/the spinal cord in the cervical spinal segments of 5-month-old rats (GM/SC) (\%)

\begin{tabular}{|c|c|c|c|c|c|c|c|c|c|}
\hline & & & \multicolumn{6}{|c|}{ Number of Animal } & \multirow{2}{*}{ MEANS } \\
\hline & & & $\mathrm{R} 1$ & $\mathrm{R} 2$ & R3 & R4 & R5 & R6 & \\
\hline \multirow{24}{*}{ 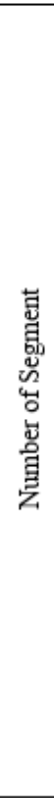 } & \multirow{3}{*}{$\mathrm{C} 1$} & VVSC & 2.584 & 2.853 & 2.240 & 2.665 & 2.527 & 2.522 & 2.565 \\
\hline & & $\mathrm{WM} / \mathrm{SC}$ & 0.560 & 0.440 & 0.450 & 0.430 & 0.480 & 0.480 & 0.470 \\
\hline & & $\mathrm{GM} / \mathrm{SC}$ & 0.300 & 0.230 & 0.390 & 0.310 & 0.220 & 0.220 & 0.270 \\
\hline & \multirow{3}{*}{$\mathrm{C} 2$} & VVSC & 2.360 & 2.812 & 2.048 & 2.652 & 2.812 & 2.221 & 2.484 \\
\hline & & $\mathrm{WM} / \mathrm{SC}$ & 0.590 & 0.440 & 0.570 & 0.460 & 0.420 & 0.560 & 0.500 \\
\hline & & $\mathrm{GM} / \mathrm{SC}$ & 0.270 & 0.220 & 0.350 & 0.250 & 0.220 & 0.180 & 0.240 \\
\hline & \multirow{3}{*}{$\mathrm{C} 3$} & VVSC & 3.085 & 3.560 & 2.086 & 2.566 & 2.175 & 1.644 & 2.519 \\
\hline & & $\mathrm{WM} / \mathrm{SC}$ & 0.420 & 0.460 & 0.570 & 0.440 & 0.360 & 0.700 & 0.490 \\
\hline & & $\mathrm{GM} / \mathrm{SC}$ & 0.230 & 0.250 & 0.330 & 0.240 & 0.330 & 0.440 & 0.300 \\
\hline & \multirow{3}{*}{$\mathrm{C} 4$} & VVSC & 2.944 & 2.932 & 2.100 & 2.536 & 2.347 & 1.932 & 2.465 \\
\hline & & $\mathrm{WM} / \mathrm{SC}$ & 0.500 & 0.420 & 0.510 & 0.410 & 0.480 & 0.610 & 0.480 \\
\hline & & $\mathrm{GM} / \mathrm{SC}$ & 0.260 & 0.250 & 0.330 & 0.280 & 0.220 & 0.280 & 0.270 \\
\hline & \multirow{3}{*}{$\mathrm{C} 5$} & VVSC & 2.928 & 2.829 & 2.628 & 2.444 & 1.978 & 1.575 & 2.397 \\
\hline & & $\mathrm{WM} / \mathrm{SC}$ & 0.400 & 0.390 & 0.390 & 0.430 & 0.450 & 0.650 & 0.450 \\
\hline & & $\mathrm{GM} / \mathrm{SC}$ & 0.220 & 0.230 & 0.260 & 0.330 & 0.180 & 0.260 & 0.240 \\
\hline & \multirow{3}{*}{$\mathrm{C} 6$} & VVSC & 3.032 & 2.606 & 2.648 & 2.639 & 1.400 & 1.041 & 2.233 \\
\hline & & $\mathrm{WM} / \mathrm{SC}$ & 0.450 & 0.410 & 0.440 & 0.450 & 0.560 & 1.020 & 0.550 \\
\hline & & $\mathrm{GM} / \mathrm{SC}$ & 0.230 & 0.230 & 0.240 & 0.260 & 0.240 & 0.330 & 0.250 \\
\hline & \multirow{3}{*}{$\mathrm{C} 7$} & VVSC & 2.048 & 1.486 & 2.220 & 2.197 & 1.784 & 1.364 & 1.849 \\
\hline & & $\mathrm{WM} / \mathrm{SC}$ & 0.490 & 0.600 & 0.520 & 0.370 & 0.530 & 0.670 & 0.530 \\
\hline & & $\mathrm{GM} / \mathrm{SC}$ & 0.160 & 0.270 & 0.340 & 0.330 & 0.180 & 0.250 & 0.250 \\
\hline & \multirow{3}{*}{$\mathrm{C} 8$} & VVSC & 1.578 & 1.546 & 1.587 & 1.580 & 1.752 & 1.357 & 1.566 \\
\hline & & $\mathrm{WM} / \mathrm{SC}$ & 0.500 & 0.660 & 0.520 & 0.520 & 0.480 & 0.630 & 0.550 \\
\hline & & $\mathrm{GM} / \mathrm{SC}$ & 0.220 & 0.230 & 0.200 & 0.200 & 0.200 & 0.250 & 0.210 \\
\hline
\end{tabular}


Table 4. Volume values of the white matter of the cervical (C) spinal cord of 5-month-old rats (Q) (VVWM) $\left(\mathrm{mm}^{3}\right)$, Volume values of the gray matter of the cervical spinal segments of 5-month-old rats (VVGM) $\left(\mathrm{mm}^{3}\right)$, Volume ratios of the gray matter/the white matter in the cervical spinal segments of 5-month-old rats (GM/WM) $(\%)$

\begin{tabular}{|c|c|c|c|c|c|c|c|c|c|}
\hline \\
\hline & & & \multicolumn{6}{|c|}{ Number of Animal } & \multirow{2}{*}{ MEANS } \\
\hline & & & R1 & R2 & R3 & R4 & R5 & R6 & \\
\hline \multirow{24}{*}{ 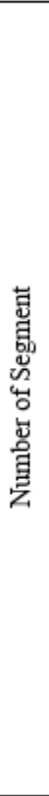 } & \multirow{3}{*}{$\mathrm{C} 1$} & VVWM & 1.471 & 1.265 & 1.023 & 1.156 & 1.215 & 1.146 & 1.212 \\
\hline & & VVGM & 0.777 & 0.670 & 0.880 & 0.839 & 0.575 & 0.555 & 0.714 \\
\hline & & GM/WM & 0.520 & 0.520 & 0.710 & 0.720 & 0.500 & 0.450 & 0.570 \\
\hline & \multirow{3}{*}{$\mathrm{C} 2$} & VWWM & 1.401 & 1.247 & 1.179 & 1.240 & 1.205 & 1.219 & 1.248 \\
\hline & & VVGM & 0.510 & 0.643 & 0.724 & 0.669 & 0.621 & 0.409 & 0.619 \\
\hline & & GM/WM & 0.460 & 0.510 & 0.610 & 0.530 & 0.500 & 0.320 & 0.480 \\
\hline & \multirow{3}{*}{$\mathrm{C} 3$} & VVWM & 1.305 & 1.673 & 1.201 & 1.152 & 0.803 & 0.790 & 1.154 \\
\hline & & VVGM & 0.710 & 0.901 & 0.704 & 0.627 & 0.723 & 0.725 & 0.731 \\
\hline & & GM/WM & 0.540 & 0.530 & 0.580 & 0.540 & 0.910 & 0.620 & 0.620 \\
\hline & \multirow{3}{*}{$\mathrm{C} 4$} & VVWM & 1.475 & 1.235 & 1.075 & 1.065 & 1.133 & 1.135 & 1.186 \\
\hline & & VVGM & 0.766 & 0.738 & 0.708 & 0.712 & 0.530 & 0.551 & 0.677 \\
\hline & & GM/WM & 0.510 & 0.590 & 0.650 & 0.660 & 0.460 & 0.460 & 0.550 \\
\hline & \multirow{3}{*}{$\mathrm{C} 5$} & VVWM & 1.187 & 1.108 & 1.049 & 1.062 & 0.896 & 0.890 & 1.032 \\
\hline & & VVGM & 0.665 & 0.656 & 0.702 & 0.813 & 0.364 & 0.420 & 0.603 \\
\hline & & GM/WM & 0.560 & 0.500 & 0.660 & 0.810 & 0.400 & 0.400 & 0.570 \\
\hline & \multirow{3}{*}{$\mathrm{C} 6$} & VVWM & 1.369 & 1.078 & 1.188 & 1.205 & 0.788 & 0.760 & 1.064 \\
\hline & & VVGM & 0.711 & 0.608 & 0.664 & 0.696 & 0.339 & 0.349 & 0.561 \\
\hline & & GM/WM & 0.510 & 0.590 & 0.540 & 0.570 & 0.440 & 0.320 & 0.490 \\
\hline & \multirow{3}{*}{ C7 } & VVWM & 1.004 & 0.895 & 0.836 & 0.833 & 0.961 & 0.964 & 0.915 \\
\hline & & VVGM & 0.341 & 0.408 & 0.765 & 0.745 & 0.336 & 0.354 & 0.491 \\
\hline & & GM/WM & 0.330 & 0.570 & 0.910 & 0.890 & 0.340 & 0.380 & 0.560 \\
\hline & \multirow{3}{*}{$\mathrm{C} 8$} & VVWM & 0.789 & 1.024 & 0.837 & 0.824 & 0.849 & 0.877 & 0.866 \\
\hline & & VVGM & 0.362 & 0.371 & 0.327 & 0.328 & 0.357 & 0.352 & 0.349 \\
\hline & & GM/WM & 0.450 & 0.360 & 0.390 & 0.390 & 0.400 & 0.400 & 0.330 \\
\hline
\end{tabular}

Cervical part of columna vertebralis in 1-month and 5-month-old male rats consisted of 7 vertebrae. In addition, 8 cervical segments were determined. Volume value increased for segments $\mathrm{C} 2$, C3, C4, and C5 when volume of whole cervical segment was evaluated in 1-month-old male rats. Volume value was also higher for segments C2, C3, C4, and C5 when evaluating the volume of cervical segment's grey matter in 1-month-old male rats. As volume value of white matter of cervical segment in 1-month-old male rats was evaluated, the highest values were determined in segments C2, C3, C4, and C5. Thus, segments C2, C3, C4, and C5 were considered to create the extension region called as cervical enlargement. When evaluating the volume of whole cervical segment in 5 month-old male rats, this value was observed mostly in segments C3, C4, C5, C6, and C7. Examination of white matter volume value of 5-month-old male rats revealed that values of C2, C3, C4, C5, C6 were higher compared to the other segments. Values of segments C3, C4, C5, and C6 were determined to be higher when examining grey matter in terms of the volume value. In the present study, this extension peaked at segment $\mathrm{C} 3$ in 5-month-old male rats, there was a considerable decrease in volume after segments $\mathrm{C} 4$, C5. Segments C3, C4, C5, and C6 were considered to create cervical enlargement in 5-month-old male rats. As mean volume was calculated for whole cervical segment in 5-month-old male rats in this study, the obtained value was about $2.259 \mathrm{~mm}^{3}$. A mean volume value of about $1.615 \mathrm{~mm}^{3}$ was obtained from the calculation of the mean of all cervical segment volume values in 1-month-old male rats. When arithmetic mean of all volume values of cervical segments in 5-month and 1-month-old male rats was compared, volume values were determined to be lower for 1-month-old rats. Segment C4 was the one where volume value of grey matter was the highest in 1-month-old male rats. When it was compared with all volume values, it was determined that segments $\mathrm{C} 2$ and $\mathrm{C} 4$ had the highest total volume. When comparing white matter volume value with all volume values, it was determined that segments $\mathrm{C} 2$ and $\mathrm{C} 4$ had the highest volume. In terms of overall volume values, the white matter volume and the volume of grey matter, the highest value in C2, C3, C4, and C5 segments, where cervical extension took place, was in parallel to each other. The highest grey matter value belonged to segments C1, C3 and C4 in 5month male rats. The highest white matter value belonged to segments $\mathrm{C} 1, \mathrm{C} 2$, and $\mathrm{C} 4$. Overall volume was determined to be the highest in segments C2, C3, and C4. Segments with increased the volume of white and grey matter, overall volume volumes were in parallel with each other. 


\subsection{Statistical Analysis}

When all spinal cord volume values were investigated, it was seen that there was not any statistical differences between 1-month and 5-month-old rats in terms of all segments studied (except for C8); whereas, there was a numeric increase. When examining segments in 1-month-old rats, the highest value belonged to segment $\mathrm{C} 1$ and the value of segment decreased as the order of segment increased (except for $\mathrm{C} 3, \mathrm{C} 5)(\mathrm{P}<0.01)$. The lowest value was determined in segment C8. As segments of 5-month-old rats were investigated, it was determined that the highest value was for $\mathrm{C} 1$ segment and segment value decreased as the order of segment increased (except for C3) $(\mathrm{P}<0.01)$. There was not any statistical differences among segments C1-6, C4-7, and C7-8 (Table 5).

Table 5. Measured values at 1 st and 5 th months for all segmental volume at male rats

\begin{tabular}{|c|c|c|c|}
\hline Segments & 1. month & 5. month & Sig. \\
\hline C1 & $2.499 \pm 0.330^{\mathrm{a}}$ & $2.565 \pm 0.082^{\mathrm{a}}$ & - \\
\hline C2 & $2.134 \pm 0.164^{\mathrm{ab}}$ & $2.484 \pm 0.131^{\mathrm{a}}$ & - \\
\hline C3 & $2.036 \pm 0.198^{\mathrm{ab}}$ & $2.519 \pm 0.287^{\mathrm{a}}$ & - \\
\hline C4 & $2.103 \pm 0.197^{\mathrm{ab}}$ & $2.465 \pm 0.172^{\mathrm{ab}}$ & - \\
\hline C5 & $2.059 \pm 0.313^{\mathrm{ab}}$ & $2.397 \pm 0.214^{\mathrm{ab}}$ & - \\
\hline C6 & $1.749 \pm 0.184^{\mathrm{bc}}$ & $2.234 \pm 0.330^{\mathrm{ab}}$ & - \\
\hline C7 & $1.314 \pm 0.206^{\mathrm{cd}}$ & $1.850 \pm 0.149^{\mathrm{bc}}$ & $*$ \\
\hline C8 & $1.067 \pm 0.099^{\mathrm{d}}$ & $1.567 \pm 0.051^{\mathrm{c}}$ & \\
\hline Sig. & $* *$ & $* *$ & \\
\hline
\end{tabular}

-: Insignificant, $*: \mathrm{P}<0.05, * *: \mathrm{P}<0.01$

a, b, c, d: The difference between the averages expressed in different letters in the same column is significant

It was observed that there was no statistical difference in all segments (except for C8) between 1-month and 5-month-old rats studied in terms of the volume values of WM. On the other hand, there was a numeric increase. When segments of 1-month-old rats were determined,that was seen the highest value was belonged to segment $\mathrm{C} 1$ and the segment value decreased as the order of segment increased (except for $\mathrm{C} 4)(\mathrm{P}<0.05)$. The lowest value was determined to be in segment $\mathrm{C} 8$. As segments of 5 month-old rats were examined in terms of WM volume values, the highest value belonged to segment C2. Segment value decreased as the order of segments increased $(\mathrm{C} 4$ and $\mathrm{C} 6)(\mathrm{P}<0.01)$. (Table 6).

Table 6. Measured values at 1 st and 5 th months of white matter volume in male rats

\begin{tabular}{|c|l|l|c|}
\hline Segments & \multicolumn{1}{|c|}{1. month } & 5. month & Sig. \\
\hline C1 & $1.019 \pm 0.081^{\mathrm{a}}$ & $1.213 \pm 0.061^{\mathrm{a}}$ & - \\
\hline C2 & $0.933 \pm 0.082^{\mathrm{ab}}$ & $1.249 \pm 0.032^{\mathrm{a}}$ & $* *$ \\
\hline C3 & $0.905 \pm 0.024^{\mathrm{ab}}$ & $1.154 \pm 0.135^{\mathrm{a}}$ & - \\
\hline C4 & $1.010 \pm 0.137^{\mathrm{a}}$ & $1.186 \pm 0.063^{\mathrm{a}}$ & - \\
\hline C5 & $0.919 \pm 0.103^{\mathrm{ab}}$ & $1.032 \pm 0.048^{\mathrm{ab}}$ & - \\
\hline C6 & $0.816 \pm 0.079^{\mathrm{ab}}$ & $1.065 \pm 0.100^{\mathrm{ab}}$ & $*$ \\
\hline C7 & $0.678 \pm 0.095^{\mathrm{bc}}$ & $0.916 \pm 0.029^{\mathrm{b}}$ & $* *$ \\
\hline C8 & $0.619 \pm 0.045^{\mathrm{c}}$ & $0.867 \pm 0.034^{\mathrm{b}}$ & $* *$ \\
\hline Sig. & $*$ & $* * 0.01$ & \\
\hline
\end{tabular}

$\mathrm{a}, \mathrm{b}, \mathrm{c}$ : The difference between the averages expressed in different letters in the same column is significant

There was no statistical difference between 1-month and 5-month-old rats in all segments (except for C8) studied in terms of GM volume values; besides, a numeric decrease (except for segment C3) was determined. In 1-month and 5-month-old rats, the difference between segments C4 and C8 and other segments was significant, respectively $(\mathrm{P}<0.05)$.

When segments of 1-month-old rats were investigated, the highest value was determined for segment $\mathrm{C} 1$ and segment value decreased as the order of segment increased (except for segment $\mathrm{C} 4$ ) $(\mathrm{P}<0.001)$. In addition, while there was not any statistical differencesamong the segments $\mathrm{C} 1-\mathrm{C} 4$, it was different from others; while there was not any statistical differences among the C2-C7 segments, it was different from others; and the lowest value was belonged to segment C8. 
When segments of 5-month-old rats were examined within themselves, it was determined that the highest value belonged to segment $\mathrm{C} 3$ and segment value decreased as the number of segment increased (except for segment $\mathrm{C} 3)(\mathrm{P}<0.001)$. Also, there was not any statistical changes between the C1-6, C2-7, and C7-8 segments (Table 7).

Table 7. The grey matter values were measured at 1 and 5 months in male rats

\begin{tabular}{|c|c|c|c|}
\hline Segments & 1 . month & 5. month & Sig. \\
\hline C1 & $0.851 \pm 0.082^{\mathrm{a}}$ & $0.716 \pm 0.056^{\mathrm{a}}$ & - \\
\hline C2 & $0.722 \pm 0.063^{\mathrm{ab}}$ & $0.620 \pm 0.044^{\mathrm{ab}}$ & - \\
\hline C3 & $0.718 \pm 0.029^{\mathrm{ab}}$ & $0.732 \pm 0.037^{\mathrm{a}}$ & - \\
\hline C 4 & $0.785 \pm 0.022^{\mathrm{ab}}$ & $0.668 \pm 0.041^{\mathrm{ab}}$ & $*$ \\
\hline C5 & $0.674 \pm 0.055^{\mathrm{bc}}$ & $0.603 \pm 0.071^{\mathrm{ab}}$ & - \\
\hline C6 & $0.637 \pm 0.048^{\mathrm{bc}}$ & $0.561 \pm 0.070^{\mathrm{ab}}$ & - \\
\hline C7 & $0.522 \pm 0.059^{\mathrm{cd}}$ & $0.492 \pm 0.084^{\mathrm{bc}}$ & - \\
\hline C 8 & $0.394 \pm 0.013^{\mathrm{d}}$ & $0.350 \pm 0.007^{\mathrm{c}}$ & $*$ \\
\hline Sig. & $* * *$ & $* * *$ & \\
\hline \multicolumn{3}{|l}{} \\
\hline
\end{tabular}

$\mathrm{a}, \mathrm{b}, \mathrm{c}, \mathrm{d}$ : The difference between the averages expressed in different letters in the same column is significant

$\mathrm{GM} / \mathrm{SC}$ volume ratios were determined to be statistically insignificant between 1-month and 5month-old rats in terms of all segments studied, except for segments $\mathrm{C} 1, \mathrm{C} 2$, and $\mathrm{C} 8(\mathrm{P}<0.01)$. As $\mathrm{GM} / \mathrm{SC}$ volume ratios were evaluated within themselves for segments of 1-month-old rats, the difference between segments was revealed to be insignificant.

When GM/SC volume ratios for segments of 5-month-old rats were examined statistically, the difference between segments was determined to be insignificant (Table 8).

Table 8. GM/SC ratio is the volume measurements at 1 and 5 months in male rats

\begin{tabular}{|c|c|c|c|}
\hline Segments & 1. month & 5. month & Sig \\
\hline $\mathrm{C} 1$ & $0.352 \pm 0.031$ & $0.473 \pm 0.019$ & *** \\
\hline $\mathrm{C} 2$ & $0.335 \pm 0.025$ & $0.507 \pm 0.031$ & $* *$ \\
\hline $\mathrm{C} 3$ & $0.365 \pm 0.038$ & $0.492 \pm 0.050$ & - \\
\hline $\mathrm{C} 4$ & $0.383 \pm 0.040$ & $0.488 \pm 0.030$ & - \\
\hline C5 & $0.348 \pm 0.041$ & $0.452 \pm 0.041$ & - \\
\hline C6 & $0.370 \pm 0.023$ & $0.555 \pm 0.095$ & - \\
\hline $\mathrm{C} 7$ & $0.433 \pm 0.075$ & $0.530 \pm 0.042$ & - \\
\hline $\mathrm{C} 8$ & $0.380 \pm 0.036$ & $0.552 \pm 0.030$ & *** \\
\hline Sig. & - & - & \\
\hline
\end{tabular}

The difference between segments was revealed to be statistically insignificant as WM/SC volume ratios were evaluated for 1-month and 5-month-old rats (Table 9).

Table 9. WM/SC ratio is the volume measurements at 1 and 5 months in male rats

\begin{tabular}{|c|c|c|c|}
\hline Segments & 1. month & 5. month & Sig. \\
\hline C1 & $0.425 \pm 0.042$ & $0.473 \pm 0.019$ & - \\
\hline C2 & $0.438 \pm 0.036$ & $0.507 \pm 0.031$ & - \\
\hline C3 & $0.465 \pm 0.053$ & $0.492 \pm 0.050$ & - \\
\hline C4 & $0.492 \pm 0.076$ & $0.488 \pm 0.030$ & - \\
\hline C5 & $0.485 \pm 0.075$ & $0.452 \pm 0.041$ & - \\
\hline C6 & $0.488 \pm 0.066$ & $0.555 \pm 0.095$ & - \\
\hline C7 & $0.538 \pm 0.061$ & $0.530 \pm 0.042$ & - \\
\hline C8 & $0.600 \pm 0.074$ & $0.552 \pm 0.030$ & - \\
\hline Sig. & - & - & - \\
\hline
\end{tabular}

-: Insignificant 
GM/WM volume ratios were statistically significant between 1-month and 5-month-old rats in segments studied in terms of segments $\mathrm{C} 1, \mathrm{C} 2, \mathrm{C} 6$ and $\mathrm{C} 8$ ( $\mathrm{P}<0.01)$. GM/WM volume ratios between segments of 5-month-old rats were statistically insignificant (Table 10).

Table 10. GM/WM ratio is the volume measurements at 1 and 5 months in male rats

\begin{tabular}{|c|c|c|c|}
\hline Segments & 1. month & 5. month & Sig. \\
\hline C1 & $0.828 \pm 0.031$ & $0.570 \pm 0.047$ & $* *$ \\
\hline C2 & $0.778 \pm 0.045$ & $0.488 \pm 0.039$ & $* *$ \\
\hline C3 & $0.790 \pm 0.031$ & $0.620 \pm 0.060$ & $*$ \\
\hline C4 & $0.853 \pm 0.123$ & $0.555 \pm 0.037$ & $*$ \\
\hline C5 & $0.757 \pm 0.074$ & $0.555 \pm 0.065$ & - \\
\hline C6 & $0.802 \pm 0.078$ & $0.495 \pm 0.041$ & $*$ \\
\hline C7 & $0.792 \pm 0.071$ & $0.568 \pm 0.110$ & $* *$ \\
\hline C8 & $0.648 \pm 0.055$ & $0.398 \pm 0.012$ & - \\
\hline Sig. & - & - & \\
\hline
\end{tabular}

Two-simple T Test was used for comparison of volume values in 1-month and 5-month-old male rats. For comparing the volume values among the cervical spinal segments One-Way Anova test was utilized. Statistical analysis was carried out by SPSS packaged software.

\section{Discussion}

In the present study, cervical segments of spinal cord were dissected, but spinal cord could not distinguished from spine completely. Because, it assisted to give name for cervical vertebrae of spine by cervical segments. Begum et al. [27] segmented spinal cord along with spine. Dissection stage of the present study is similar to the study by Begum et al. [27].

In various studies in the literature [5, 28-30] the cervical segments'number in rats was stated to be 8 cervical segments which was one more than the number of cervical vertebrae. The cervical segments' number was 8 in the present study, as well.

In the study conducted on Leghorn chicken, enlargement of cervical segment was found to be composed by C13, C14, C15, T1, T2 segments [31]. Baumel [32] and Haziroglu et al. [33] stated that cervical enlargement in poultry was created by the the first two thoracic segments and last three cervical segments. Nickel et al. [34] reported that it was composed of the last two cervical and T1, T2, and sometimes T3. Zeman and Maitland [5] indicated that the expansion of cervical segment in rats started from segment $\mathrm{C} 4$ and continued to segment $\mathrm{C} 8$. In the present study, segments $\mathrm{C} 2, \mathrm{C} 3, \mathrm{C} 4$, and $\mathrm{C} 5$ were observed to form the extension part, which is called as cervical enlargement, in 1-month -old male rats. This study revealed that the extension peaked at volume of segment C3 in 5-month-old male rats, there was an apparent decrease in volume value after segments $\mathrm{C} 4$ and $\mathrm{C} 5$. It was determined in the present study that cervical enlargement corresponded to segments C3, C4, and C5. There was no study in the literature identifying the segment where cervical enlargement is located in male rats based on the age. In the studies on intertransversal cross sections of spinal cord from Leghorn chickens, it was determined as a result of volume calculations that total volume of white matter was $1007 \pm 127 \mathrm{~mm}^{3}$ in females and $1400.7 \pm 94.1 \mathrm{~mm}^{3}$ in males. Measurements of grey matter indicated that volume of grey matter was $241.4 \pm 26.8 \mathrm{~mm}^{3}$ in females and $311.4 \pm 23.4 \mathrm{~mm}^{3}$ in males. When total volume of grey matter was compared to total volume of spinal cord in the study, the results were obtained as $19.36 \% \pm 0.882$ in females and $18.19 \% \pm 0.706$ in males [31].

In the current study, it was revealed that the white matter's total volume was $0.861 \mathrm{~mm}^{3}$ in 1month-old male rats; whereas, the white matter's total volume was $1.081 \mathrm{~mm}^{3}$ in 5 -month-old male rats. While total volume of grey matter was $0.662 \mathrm{~mm}^{3}$ in 1-month-old male rats, volume value of grey matter was $0.591 \mathrm{~mm}^{3}$ in 5-month-old male rats. Thus, total volume of grey matter was determined to decrease in 5-month-old rats. However, volume value of grey matter in 1-month-old male rats was higher than volume of grey matter in 5-month-old male rats.

In the study on Leghorn chicken [31], volume ratio of grey matter was found to be higher at pars caudalis and lumbosacral part in females; this was the highest at caudal part in males. Rahmanifar et al. [35] studied on ostrich and identified that grey matter was found most intensively in pars lumbalis. 
In a study which was on Leghorn chicken [31], cervical part was revealed to be a part where grey matter to whole spinal cord ratio was the lowest in females and males, the highest ratio was at thoracic part. Rahmanifar et al. [35], in their study on mature ostrich, stated that cervical part had the lowest of the ratio of grey matter and the lowest amount of the grey matter was more intensive in thoracic part and lumbar part compared to cervical part. In the present study, on the other hand, mean ratio for the grey matter's volume to spinal cord's total volume was found to be 0.36 in 1-month-old male rats. This ratio was 0.25 for 5 -month-old male rats. This volume ratio was higher in 1-month-old male rats than 5month-old male rats, it decreased in adult rats, and also the grey matter's volume was smaller in 5month-old male rats.

In morphometric studies on horse [36], ape [37], donkey [38], human [39] and rat [40]. areas and white matter's and grey matter's area ratios in lumbal segments of spinal cord were represented as parameter. In conclusion; volumes and volume ratios of all cervical segments, spinal cord's white and grey matters in 1-month and 5-month-old male rats were obtained using morphological and stereological methods in the present study. The results were given in tables. The results of the present study were considered to contribute to the global literature. We also concluded that the present study can shine light on further studies.

\section{Acknowledgements}

This study was studied at Van Yuzuncu Yil University.This is an article from master thesis. We are grateful for the support of Presidency Project Scientific Research of Van Yuzuncu Yil University. For this study Presidency of Project Scientific Research of Van Yuzuncu Yil University was source of funding. Code of Project: 2014-SBE-YL029/ID: 1291 This study was summarized from master thesis of first author. By Van Yuzuncu Yil University Animal Researches Local Ethic Committee the final report of the research project detailed above was approved in the session held on 12/26/2017 (decision number 2016/09).

\section{Authors' Contributions}

Cakmak G. as corresponding author contributed $60 \%$ to this study, Candan M. contributed $40 \%$.

\section{Statement of Conflicts of Interest}

There is no conflict of interest betwwen the authors.

\section{Statement of Research and Publication Ethics}

The author declares that this study complies with Research and Publication Ethics.

\section{References}

[1] Ide T. 2003. Animal Models. Laboratory Animals, Basic Principles of Science. Turkish translation, Zutphen LFM, Baumans V, Beynen AC. In: Ide T, Translation ed. Medipres Publications, Ozkan Typography, Ankara.

[2] Deniz G., Oral B. 2011. Experimental Animal Modeling Workshop. The Official Turkish Journal of Society of Immunology. 1: 10-18.

[3] Dursun N. 2000. Veterinary Anatomy III. Medisan Publishing, 15-23pp. Ankara.

[4] Arinci K., Elhan A. 2001. Anatomy. Vol 1. 3rd ed., Gunes Publishing, 59-65p. Ankara.

[5] Zeman W., Maitland J.M. 1963. Cragie's Neuroanatomy of the Rat (Revised and expanded). In Academic Press Inc, 230p. New York.

[6] Dursun N. 2008. Veterinary Anatomy I. 7th ed., Medisan Publishing, 15-67 pp. Ankara.

[7] Bahadir A., Yildiz H. 2010. Veterinary anatomy movement system and internal organs. 3rd ed., Ezgi Publishing, 37-56p. Istanbul.

[8] Unur E., Ulger H., Ekinci N. 2002. Anatomy. Ufuk Publishing, Kayseri. 
[9] Schoenen J., Faull R.L.M. 2004. Spinal cord cyto and chemoarchitecture. The human nervous system. In: George Paxinos JKM, 2nd ed., Elsevier Academic Press, 190-228 pp. London.

[10] Tanyolac A. 1993. Special Histology. 23-24p.

[11] Cruz-Orive L.M., Weibel E.R. 1990. Recent stereological methods for cell biology: a brief survey. Lung Cellular and Molecular Physiology. American Journal of Psychology, 258, 148156.

[12] Baddeley A.J. 1991. Stereology. Spatial statistics and digital image analysis. In: DC: Natural Research Company Ed., Washington.

[13] Gundersen H.J. 1986. Stereology of arbitrary particles. A review of unbiased number and size estimators and the presentation of some new ones. In: memory of William R. Thompson, Journal of Microscopy, 143: 3-45.

[14] Gundersen H.J, Jensen E.B. 1987. The efficiency of systematic sampling in stereology and its prediction. Journal of Microscopy, 147: 229-263.

[15] Howard C.V., Reed M.G. 1998. Unbiased Stereology: Three-dimensional measurement in microscopy. 1st ed., BIOS Scientific Publishers, UK.

[16] Garcia-Finana M., Cruz-Orive L.M., Mackay C.E. 2003. Comparison of MR imaging against physical sectioning to estimate the volume of human cerebral compartments. Neuroimage. 18: 505-516.

[17] Turgut M., Turkkanitunc A., Aslan H. 2007. Effect of pinealectomy on the morphology of the chick cervical spinal cord: A stereological and histopathological study. Brain Research, 1129: 166-173.

[18] Slomianka L., West M.J. 2005. Estimators of the precision of stereological estimates: An example based on the CA1 pyramidal cell layer of rats. Neuroscience, 136: 757-767.

[19] Gundersen H.J.G., Jensen E.B.V., Kieu K. 1999. The efficiency of systematic sampling in stereology- reconsidered. Journal of Microscopy, 193: 199-211.

[20] Canan S., Sahin B., Odac1 E. 2002. A stereological method used to calculate total volume, volume density and volume ratios: Cavalieri principle. Clincal Turkey Journal of Medical Science, 22: 7-14.

[21] Gundersen H.J.G., Bendtsen T.F., Korbo L. 1988. Some new, simple, and efficient stereological methods and their use in pathological research and diagnosis. Acta Pathologica Et Microbiologica Scandinavica Section A-Pathology, 96: 379-394.

[22] Royet J.P. 1991. Stereology: a method for analysing images. Prog Neurobiology. 37: 433-474.

[23] Sahin B., Aslan H., Unal B. 2001. Brain volumes of the lamb rat and bird do not show hemispheric asymmetry: a stereological study. Image Analysis and Stereology, 20: 9-13.

[24] Mis L., Eski F., Yeltekin A.C. 2018. Plasma Macro and Trace Element Levels of Male Rats Vaccinated with GnRH Hormone. Fresenismus Environmental Bulletin, 27: 5085-5090.

[25] Bancroft J.D., Stivens A., Turner D.R. 1996. Theory and practice of histological technique. 4th ed., Churchill Livingstone, 15: 76-81.

[26] Odaci E., Bahadir A., Yildirim S. 2005. Volume Calculation and Clinical Use of Computerized Tomography and Magnetic Resonance Images Using Cavalieri Principle. Turkish Journal of Veterinary and Animal Science, 25: 421-428.

[27] Begum F., Zhu W., Namaka M.P. 2010. A novel decalcification method for adult rodent bone for histological analysis of peripheral-central nervous system connections. Journal of Neuroscience Methods, 187: 59-66.

[28] Waibl H. 1973. Zur Topographie der Medulla spinalis der Albinoratte (Rattus norvegicus). Advances in Anatomy, Embryology and Cell Biology, 47: 5-42.

[29] Fritzgerald M.J.T. 1987. Anatomy and embriyology of the laboratory rat. Journal of Anatomy. 153: 256.

[30] Paxinos G. 2004. The Rat Nervous System. 3rd ed. Prince of Wales Medical Research Institute The University of New South Wales Sydney, Australia.

[31] Bolat D., Tipirdamaz S. 2011. Examination of spinal cord by stereological methods in leghorn chickens. Doctorate Thesis, University of Selcuk, Health Sciences Institute, Konya.

[32] Baumel E. 1966. Comparable neurology of domestic animals. Turkish Journal of Veterinary and Animal Science, 203-289. 
[33] Haziroglu R.M., Orhan I.O., Yildiz D. 2001. Morphology of the spinal cord in the chicken, duck and pigeon. Turkish Journal of Veterinary and Animal Science, 25: 913-920.

[34] Nickel R., Schummer A., Seiferle E. 1977. Anatomy of the domestic birds. Parey New york: Springer-Verlag, Berlin.

[35] Rahmanifar F., Mansouri S., Ghazi S. 2008. Histomorphometric study of the spinal cord segments in the chick and adult male ostrich (Struthio camelus). Iranian Journal of Veterinary Research, 4: 336-340.

[36] Braun A. 1950. Der segmentale feinbau des rückenmarks des pferdes. Acta Anatomica Basel. 10: $1-76$.

[37] Thomas C., Combs C.M. 1965. Spinal cord segments. B. Gross structure in the adult monkey. American Journal of Anatomy, 116: 205-216.

[38] Ocal M., Haziroglu R.M. 1988. Comparative morphological studies on the spinal cord of the donkey (Equus asinus L.). Examination of transversal sections of segments. Veterinary Journal of Ankara University. 35: 55-68.

[39] Ko H., Park J.H., Shin Y.B. 2004. Gross quantitayive measurements of spinal cord in human. Spinal Cord, 42: 35-40.

[40] Portiansky L., Barbeito C.G., Goya R.G. 2004. Morphometry of cervical segments grey matter in the male rat spinal cord. Journal of Neuroscience Methods, 139: 217-229. 